\title{
Pollen Morphology of Some Species of the Genus Sansevieria Petagna (Asparagaceae)
}

\author{
Malgorzata Klimko ${ }^{1}$, Renata Nowińska ${ }^{1 *}$, PaUl Wilkin ${ }^{2}$, \\ JUSTYNA WILAND-SZYMAŃSKA ${ }^{3}$ \\ ${ }^{1}$ Department of Botany, Poznań University of Life Sciences, Wojska Polskiego 71 C, \\ 60-625 Poznań, Poland \\ ${ }^{2}$ Royal Botanic Gardens, Kew, Richmond, Surrey, TW9 3AB, UK \\ ${ }^{3}$ Department of Plant Taxonomy, Adam Mickiewicz University, Umultowska 89, \\ 61-614 Poznań, Poland
}

Received February 15, 2017; revision accepted June 27, 2017

\begin{abstract}
Pollen grains of 15 species of the genus Sansevieria were examined using light and scanning electron microscopy. The pollen grains were single, but dyads were also found. The basic shape of the pollen grains (with chemical treatment) was subprolate, prolate and prolate-spheroidal and the pollen grains were large $(>50 \mathrm{~mm})$. The pollen grains observed in SEM were prolate-spheroidal, subprolate, prolate and perprolate. The aperture occupied nearly the entire distal hemisphere. The surface of non-apertural areas was microreticulate, psilate-perforate, fossulate and verrucate. The surface of the apertural area was psilate-perforate-verrucate, microreticulate-verrucategemmate and psilate-perforate. The tectum was homogeneous, with perforations. Our results suggest that some species cannot be separated based on pollen grain morphology, but only may be categorized into their groups. The present study investigated pollen grain morphology in eleven species for the first time in terms of pollen micromorphology and provided some important new data.
\end{abstract}

Keywords: pollen variability, micromorphology, taxonomy, SEM

\section{INTRODUCTION}

Sansevieria comprises ca. 60 species worldwide, mainly in dry or arid areas of the Old World tropics and subtropics (Brown, 1915; Bos, 1998; Staples and Herbst, 2005; Mabberley, 2008). Africa is the center of diversity for Sansevieria with some species distributed in the Arabian Peninsula, South Asia, and Southeast Asia (Brown, 1915; Morgenstern, 1979; Mabberley, 2008). Plants are usually xerophytic perennials that are often rhizomatous, and they may be herbs, shrubs or trees (Staples and Herbst, 2005). Some species have medicinal and horticultural value (Chahinian, 1985; Neuwinger, 1986; Bos, 1998; Staples and Herbst, 2005). The genus Sansevieria has been variously included in the families Liliaceae (Brown, 1915), Agavaceae (Cronquist, 1968; Takhtajan, 1969; Hutchinson, 1964), Dracenaceae (Salisbury, 1866; Watson and Dalwitz, 1992; Bos, 1998), Ruscaceae (APG II, 2003), and now the
Asparagaceae subfamily Nolinoideae (APG III, 2009). By some authors it is regarded only as a clade within the genus Dracaena Vandelli ex Linneus (Bos, 1998; Lu and Morden, 2014), but it is still recognized as a separate genus by other authors (Jankalski, 2009; Mansfeld, 2015), which is in line with our point of view. Phylogenetic relationships among African Sansevieria species are discussed by Lu and Morden (2014), where Sansevieria is monophyletic and nested within Dracaena. The first classification on a subgenus level for Sansevieria based on the inflorescence type was proposed by Pfenning (Pfenning, 1977 in Mansfeld, 2015) but without formal names. This work was followed by a paper by Newton with a key to more species groups (Newton, 2001 in Mansfeld, 2015). Another division of the genus into sections made by Mwachala and Mbugua (2007) was not validly published (Jankalski, 2009). Subsequently, Jankalski (2009) proposed sections based on the inflorescence types: Sansevieria sect. Sansevieria,

\footnotetext{
*Corresponding author, email: renata.nowinska@mail.up.poznan.pl
} 
Sansevieria sect. Dracomima Jankalski and Sansevieria sect. Cephalanta Jankalski. The complication of the division of the Sansevieria species into sections and subsections was made by Mansfeld (2015). The most important taxonomic treatments are mainly based on morphological characters (Brown, 1915; Couper, 2011).

Only a few species of Sansevieria have been analyzed with respect to pollen morphology. In this genus, pollen grains have been described as monoulcerate by Erdtman (1952), Ojeda et al., (1984), Ojeda Revah and Ludlow-Wiechers (1995), Hesse et al. (2009), Buchner and Halbritter (2010) and Halbritter (2010) or anaporate by Erdtman and Vischnu-Mitre (1958). Sansevieria pollen grains are also reported as monosulcate (Rudall and Campbell, 1998, Rudall et al., 2000; Kameshvari, 2011). Monosulcate pollen is considered to be a plesiomorphic feature in monocots and basal angiosperms (Halbritter and Hesse, 1993; Sampson, 2000; Furness and Rudall, 1999; 2000; 2001). A single aperture at the distal pole characterizes gymnosperm taxa of a higher rank, e.g., Cycadopsida, Bennettitopsida and
Ginkgopsida (Audran and Masure, 1978; Zavialova et al., 2011; Korszun and Klimko, 2014).

The main aim of this study was to describe the morphology of fifteen species of the genus Sansevieria and to define the rank of the diagnostic features of grains in the species under study. Another goal was to recognize pollen morphology in the genus Sansevieria in the scope of the recent taxonomic works dividing this genus into smaller subgroups.

\section{MATERIAL AND METHODS}

Flowers of 15 species of Sansevieria obtained from herbarium specimens deposited at the Royal Botanic Gardens, Kew (K), the Botanical Garden Berlin-Dahlem (B) and the Botanical Garden in Poznan (BG AMU) were studied. A list of the analyzed species, with their affiliation to sections and subsections is shown in Table 1 . The pollen grains were examined using light microcopy (LM) and scanning electron microscopy (SEM). The SEM observations were made on the dry pollen grains,

TABLE 1. List of the analyzed species.

\begin{tabular}{|c|c|c|c|c|}
\hline Section & Subsection & Species & Country of origin & Voucher \\
\hline \multirow[t]{8}{*}{ Sansevieria } & Sansevieria & ${ }^{*}$ S. hyacinthoides (L.) Druce & South Africa & Schlieben $10570(\mathrm{~K})$ \\
\hline & & S. parva N. E. Br. & $\begin{array}{l}\text { East Africa } \\
\text { unknown }\end{array}$ & $\begin{array}{l}\text { cult., Kew, Pfenning } 1034(\mathrm{~K}) \\
\text { cult. BG AMU, I_- } \\
\text { I001_004_0000_6977_1231 }\end{array}$ \\
\hline & & S. parva N. E. Br. (dooneri) & Kenya & cult. Kew, Brandham \& Cutler 01929 \\
\hline & & S. roxburghiana Schult. \& Schult. & unknown & cult. Kew, Marchward 631310 \\
\hline & & S. trifasciata Prain & Cameroon & Lowe $3035(\mathrm{~K})$ \\
\hline & Hastifolia & ${ }^{*}$ S. cylindrica Bojer ex Hook & Angola & s. coll. s. n. (K) K000204052 \\
\hline & & S. pearsonii N. E. Br. & Zambia & Fanshawe $6946(\mathrm{~K})$ \\
\hline & Stolonifera & ${ }^{*}$ S. suffruticosa N. E. Br. & Kenya & Tweedie $3666(\mathrm{~K})$ \\
\hline \multirow[t]{5}{*}{ Dracomima } & & $\begin{array}{l}\text { S. arborescens Cornu Gérôme } \\
\text { et Labroy }\end{array}$ & Tanzania & Faulkner $1827(\mathrm{~K})$ \\
\hline & & S. bagamoyensis N. E. Br. & Tanzania & Bally 13309 (B), \\
\hline & & ${ }^{*}$ S. ehrenbergii Schweinf. ex Baker & Kenya & Hensley $1256(\mathrm{~K})$ \\
\hline & & $\begin{array}{l}\text { S. perrotii Warb. } \\
\text { (S. robusta N. E. Br.) }\end{array}$ & Kenya & $\begin{array}{l}\text { Pfenning, Herford } \\
\text { Pf } 1023 \mathrm{~S}(\mathrm{~B})\end{array}$ \\
\hline & & S. powellii N. E Br. & Kenya & Rauh Ke 875 (B) \\
\hline \multirow[t]{2}{*}{ Cephalantha } & & ${ }^{*}$ S. kirkii Baker & Tanzania & Faulkner $1989(\mathrm{~K})$ \\
\hline & & S. sambiranensis Perrier & Madagascar & Phillipson 2023 (K) \\
\hline
\end{tabular}

\footnotetext{
* Type species for the section or subsection.
} 
while for LM the pollen grains were macerated with 10\% KOH (Dyakowska 1959; Frederiksen, 1978). The length of the long axis (LA), the length of the short axis (SA) and the exine thickness (Ex) were measured under LM using an Olympus microscope model BX 43 with a camera. A total of 50 pollen grains per specimen of each species were used for these measurements and the LA/SA ratio was calculated. Overall 800 pollen grains were examined. Micrographs were taken with a SEM type EVO 40 microscope (Carl Zeiss, Jena, Germany) at an accelerating voltage of $15 \mathrm{kV}$, at the Confocal and Electron Microscopy Laboratory, the Faculty of Biology, Adam Mickiewicz University, Poznań, Poland. Prior to observations, the prepared material was sputtered with gold using an SCB 050 ion sputter. The study was documented with photographs taken during observations, mostly magnified x 2000 to x 5000 for the shape and $\mathrm{x} 10000$ for the exine sculpture. SEM micrographs were used mainly to investigate the overall shape, type of sculpturing, and to obtain more detailed information on the sculpturing. The micromorphological features of the pollen grains were observed in proximal and distal views. The pollen terminology was adopted from Faegri and Iversen (1989), and Halbritter et al. (2007), while the shape classification followed that of Erdtman (1952).

The minimal and maximal values of characteristics as well as arithmetical means and the coefficient of variability were calculated (Tab. 2). Prior to the one-way ANOVA, the distribution of each studied feature and homogeneity of variance were checked with Shapiro-Wilk's and Levene's tests. Because some of the data did not meet the assumptions concerning distribution and variance, all the data were logarithmically transformed to better approximate normality and homogeneity. Next, the one-way analysis of variance (ANOVA) and post-hoc HSD Tukey's test were used to examine differences in the mean values among the characters of the studied species. In ANOVA, the homoscedasticity was checked based on scatter plots between the predictors and the residuals. Moreover, the differences between the analyzed species were visualized by the cluster analysis using the nearest neighbors method on Euclidean distances (Watała, 2002). Statistical analyses were performed using Statistica 12.5 for Windows software.

\section{RESULTS}

The general morphology of pollen grains is similar, as all are distally ulcerate. Pollen grains of Sansevieria are heteropolar, mainly monads, but dyads are also found, e.g., in
S. arborescens (Fig. 1c), S. kirkii (Fig. 7b) and in S. sambiranensis.

The studied species differ significantly in terms of all analyzed features of the pollen grains (ANOVA, $p<0.0001$ ). The mean length of the long axis (LA) of pollen grains ranges from $57.0 \mathrm{~mm}$ in $\mathrm{S}$. sambiranensis to $83.3 \mu \mathrm{m}$ in S. cylindrica, while the length of the short axis (SA) ranges from $43.6 \mu \mathrm{m}$ in $S$. sambiranensis to $77.1 \mu \mathrm{m}$ in S. cylindrica (Tab. 2). The shape of pollen grains ranges from prolatespheroidal $(\mathrm{LA} / \mathrm{SA}=1.09-1.11)$, subprolate $(\mathrm{LA} / \mathrm{SA}=1.18-1.33)$ to prolate $(\mathrm{LA} / \mathrm{SA}=$ $=1.35-1.39$ ), (Tab. 2). Dry pollen grains observed in SEM are prolate-spheroidal $(60.2 \%)$, subprolate $(26.6 \%)$, prolate $(6.6 \%)$ and perprolate $(6.6 \%)$. Values of LA, SA, and the LA/SA ratio (Tab. 2) show variability from low to moderate $(\mathrm{LA}=5.8-19.2 \%$; $\mathrm{SA}=8.6-26.9 \%$; $\mathrm{LA} / \mathrm{SA}=9.6-31.1 \%)$. The outline is circular in polar proximal and distal views and elliptic in the equatorial view. Pollen grains are large according to Erdtman's classification (1952). The mean exine thickness (Ex) ranges from 1.28 (S. sambiranensis) to $1.78 \mu \mathrm{m}$ (S. trifasciata) and is characterized by low variability, except for S. kirkii and S. pearsonii (Tab. 2). According to the Tukey's post-hoc tests $(\mathrm{P}<0.05)$, the studied species form six homogeneous groups for the SA characteristic, four homogeneous groups for the LA and Ex features and tree groups for LA/SA. In the case of LA/SA and Ex, homogeneous groups are considerably more overlapped, as compared to LA and SA (Tab. 2).

Ornamentation of all the pollen grains is not uniform but differs between proximal face and distal pollen region. Exine ornamentation on the proximal surface is: microreticulate in S. dooneri (Fig. 4b), S. ehrenbergii (Fig. 5b), psilate-perforate in S. kirkii (Fig. 7a), S. parva (Fig. 8b), S. trifasciata (Fig. 15d) and fossulate in S. hyacinthoides (Fig. 6a). The aperture occupies nearly the entire distal hemisphere and is variable in shape, e.g., flat in S. cylindrica (Fig. 3), S. parva (Fig. 8a), S. powellii (Fig. 10b), S. perrotti (Fig. 11b), S. trifasciata (Fig. 15c), convex in S. arborescens (Fig. 1c) and in S. bagamoyensis (Fig. 2b) or partly convex in S. arborescens (Fig. 1a), S. ehrenbergii (Fig. 5c), S. roxburghiana (Fig. 12a) and in S. trifasciata (Fig. 15f), slightly or fairly swollen in S. arborescens (Fig. 1b), S. hyacinthoides (Fig. 6c) and in S. kirkii (Fig. 7b). A circular or oval rim surrounding the aperture region is distinct in the periphery of dry pollen grains and its width ranges from $4.1 \mu \mathrm{m}$ (S. hyacinthoides) to $6.6 \mu \mathrm{m}$ (S. trifasciata). The ornamentation of the subhemispherical rim in most species is psilate-perforate, but in S. perrotii 


$$
\begin{aligned}
& \text { 己 ฮ }
\end{aligned}
$$

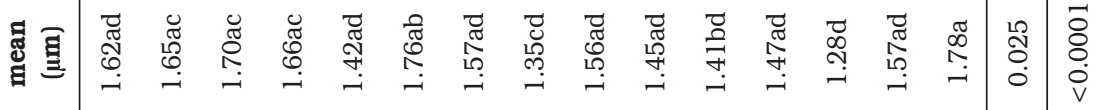

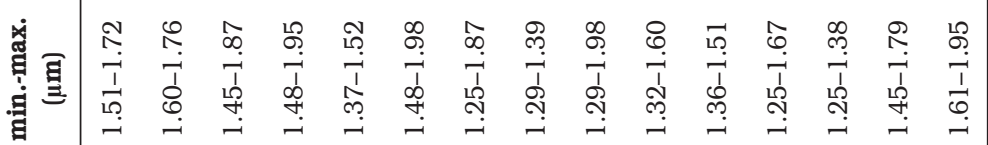

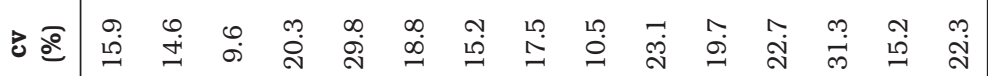

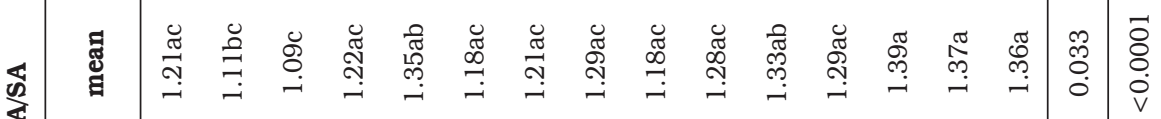

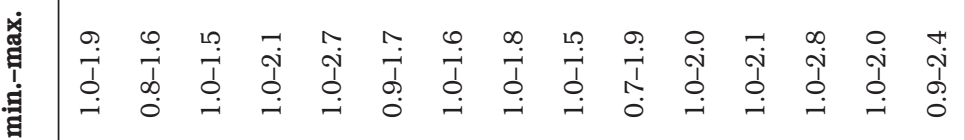

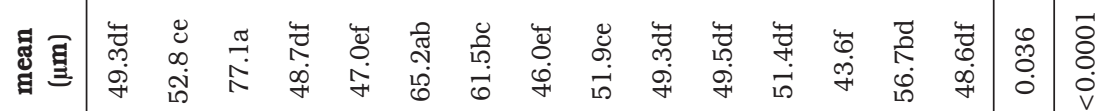

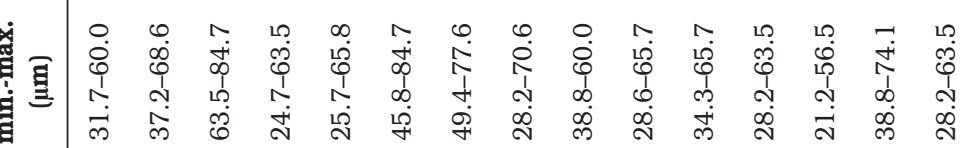
己

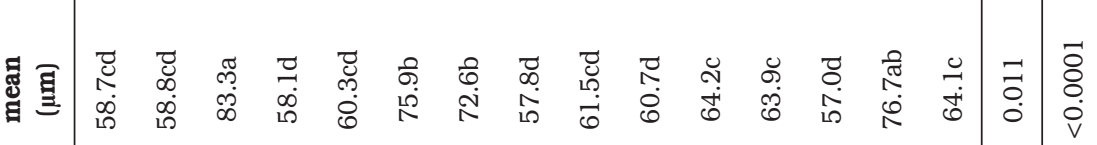

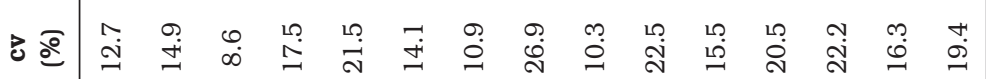

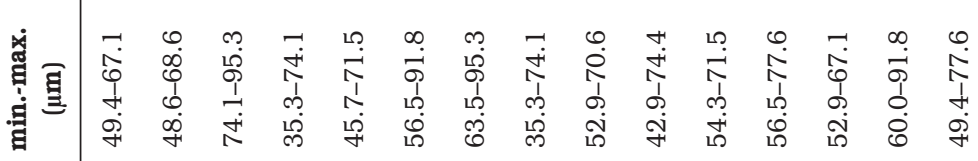



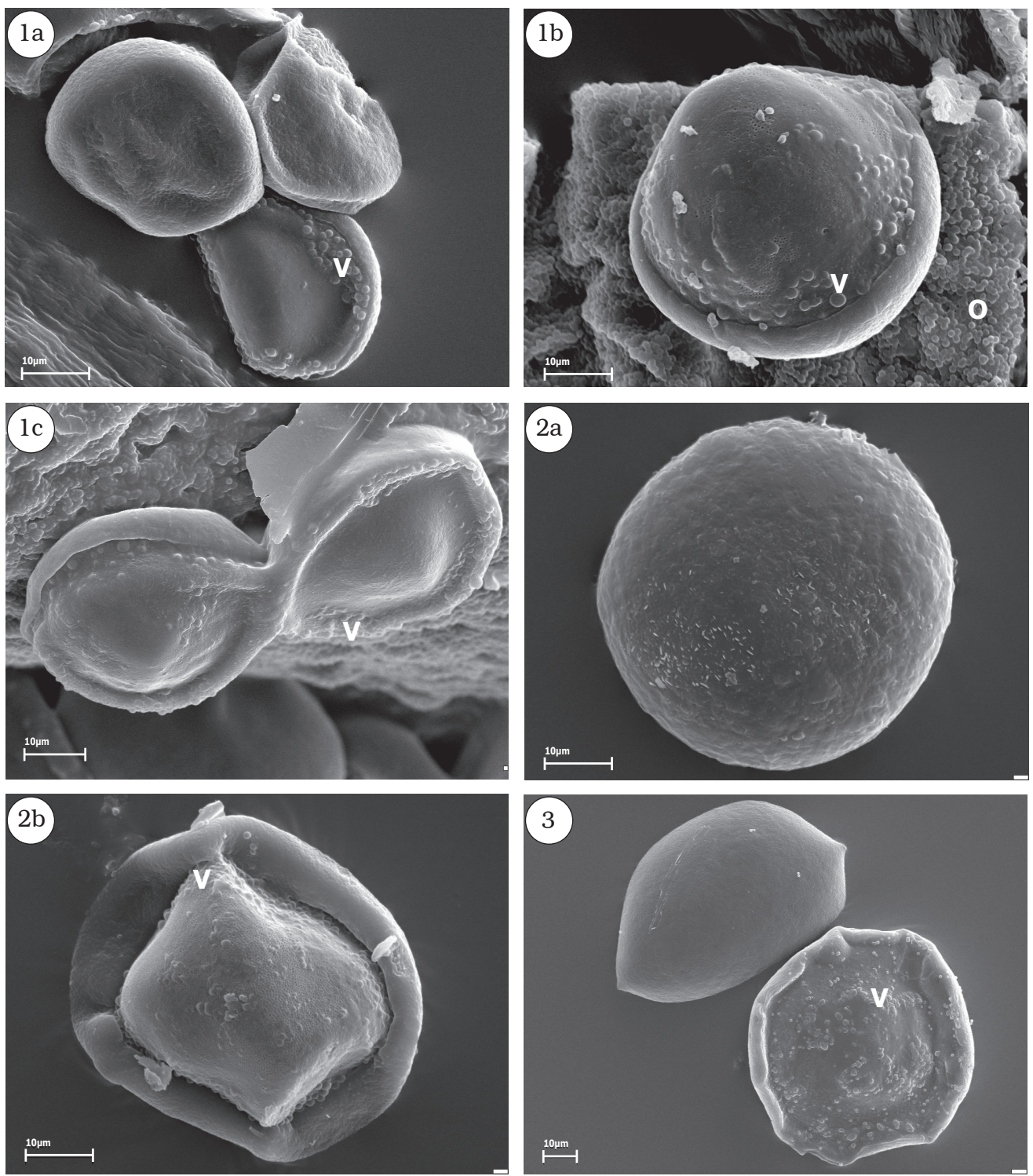

Figs. 1-3. SEM micrographs of pollen grains in Sansevieria: (1) S. arborescens (1a) in proximal and distal view, (1b) in distal view, (1c) dyad in distal view; (2) S. bagamoyensis (2a) in proximal view, (2b) in distal view; (3) S. cylindrica in proximal and distal view; $O$ - orbicule, $V$ - verrucae.

$(=$ S. robusta) and $S$. trifasciata it is covered by verrucae (Figs. 11b, 15f).

The sculpture on the apertural region is psilate-perforate-verrucate in S. arborescens (Fig. 1a), S. bagamoyensis (Fig. 2b), S. cylindrica (Fig. 3), S. hyacinthoides (Fig. 6c), S. kirkii (Fig. 7a), S. pearsonii (Fig. 9b), S. powellii (Fig. 10b), and in S. perrotti (Fig. 11b), microreticulate-verrucate-gemmate in S. ehrenbergii (Fig. 5c) and in S. trifasciata (Fig. 15a), psilate-perforate in S. kirkii (Fig. 7c). In S. sambiranensis (Fig. 13) the entire germinal membrane was covered by verruculae and the color of the pollen is violet, as in S. bagamoyensis.

The dendrogram plotted on the basis of agglomerative grouping in the nearest neighbor method on Euclidean distances shows that all the examined Sansevieria species are divided into two groups (Fig. 16). The first group comprises 11 species, from three sections while the other includes three species from two sections and three subsections. A separate position is taken by S. cylindrica. 

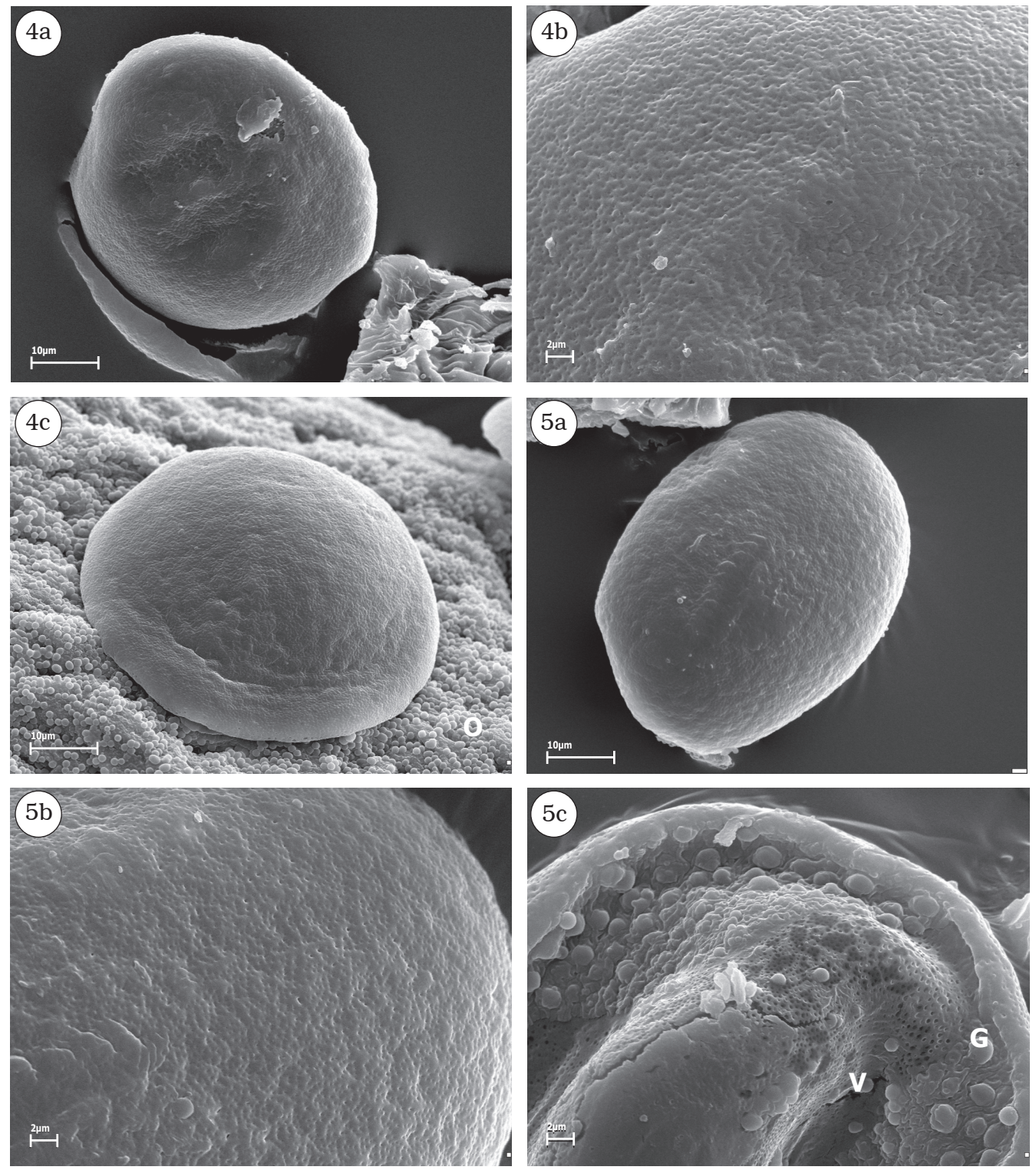

Figs. 4, 5. SEM micrographs of pollen grains in Sansevieria: (4) S. dooneri (4a) in proximal view, (4b) exine surface, enlargement of $4 \mathrm{a},(\mathbf{4 c})$ in proximal view; (5) S. ehrenbergii (5a) in proximal view, (5b) exine surface, enlargement of $5 \mathrm{a}$, (5c) in distal view; $G$ - gemmae, $O$ - orbicule, $V$ - verrucae.

\section{DISCUSSION}

The comparison of our data, with those published by other authors reveals some differences (Tab. 3). The pollen grains of S. cylindrica reported by us are larger, and the exine ornamentation on the proximal surface is psilate-perforate, contrary to smaller grains with a psilate exine ornamentation described so far (Ojeda et al., 1984; Ojeda Revah and Ludlow-Wiechers, 1995).
Dimensions of pollen grains of $\mathrm{S}$. dooneri are mostly within the range reported by Halbritter (2010) being about $58 \mu \mathrm{m}$, but they tend to be smaller (Tab. 3). The pollen grains of S. suffruticosa, observed in this study, are within the range described by Buchner and Halbritter (2010). The aperture type reported for both species is ulcerate (Halbritter, 2010; Buchner and Halbritter, 2010), consistent with the findings of our study. However, there is a difference in the observations of the exine ornamentation (Tab. 3). Additional differences of pollen grains between S. dooneri and S. suffruticosa are found 

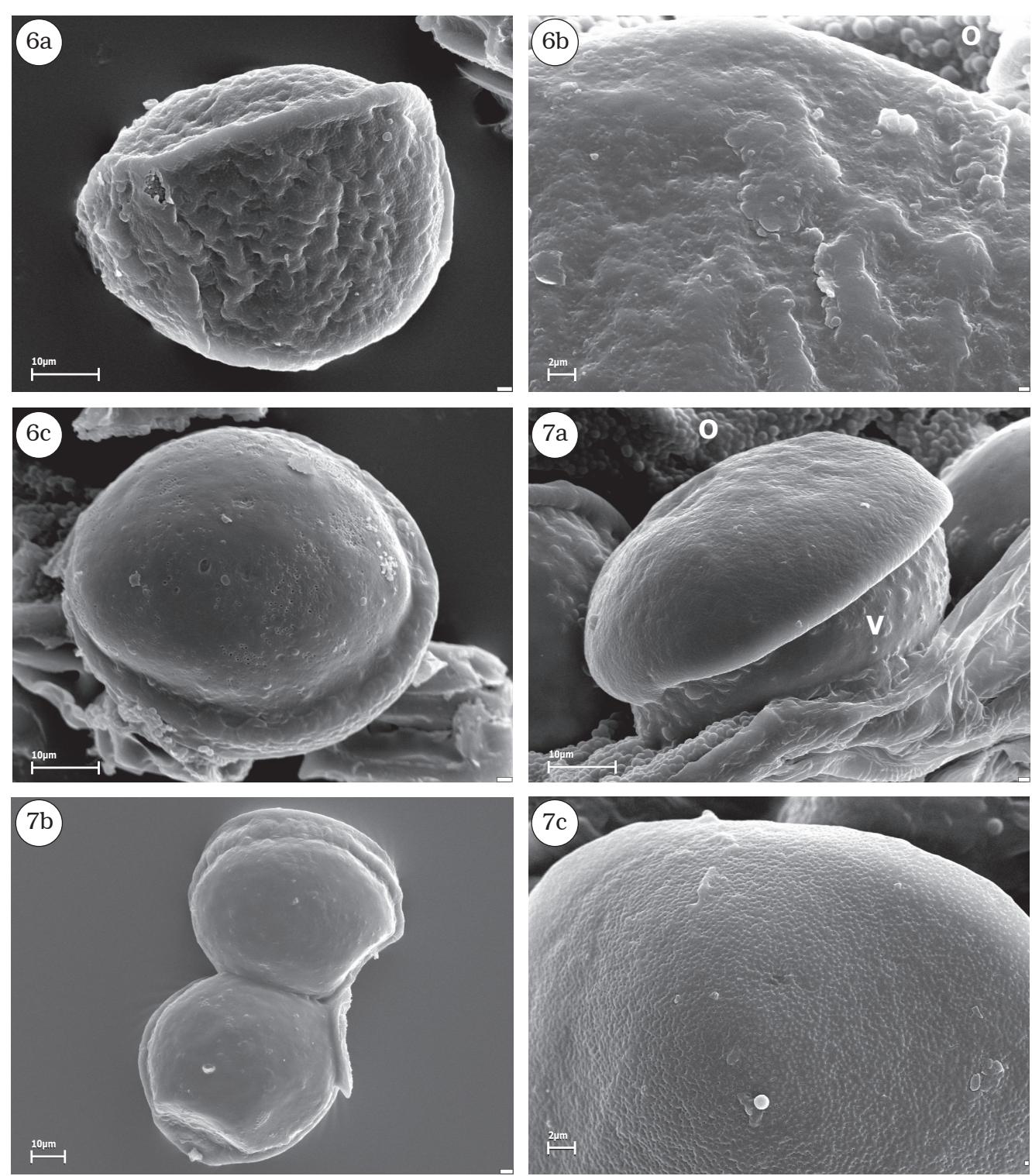

Figs. 6, 7. SEM micrographs of pollen grains in Sansevieria: (6) S. hyacinthoides (6a) in proximal view, (6b) exine surface, enlargement of $6 a,(6 \mathbf{c})$ in distal view; (7) S. kirkii (7a) in lateral view, (7b) dyad in distal view, (7c) exine surface on distal face; $O$ - orbicule, $V$ - verrucae.

in their shapes (Tab. 3), which are described by the SA/LA ratio. The LA/SA and SA/LA ratios are standard measures used in palynological studies (Özler and Pehlivan, 2010; Wrońska-Pilarek et al., 2016). The SEM photos of S. dooneri and S. suffruticosa collected in a palynological database PalDat (http://www. paldat.org), are similar to those in the present study.

The pollen grains of $S$. roxburghiana described by Kameshwari (2011) are much smaller and with a different LA/SA ratio in comparison to this study (Tab. 3). The exine ornamentation was reported by this author as smooth, while in our study the exine ornamentation on the proximal surface was psilateperforate and psilate-verrucate on the distal surface.

In the studied species the aperture occupies nearly the entire distal hemisphere and is variable in shape. The tectum in pollen grains of the studied species and in those described in the literature has a perforated surface. Sahashi and Ueno (1986), Tekleva et al. (2007) and Zavialova et al. (2011, 2014) published photos of pollen grains very similar to Sansevieria with swollen apertural areas and the apertural area with a rim in Ginkgo biloba and Cycas revoluta. 

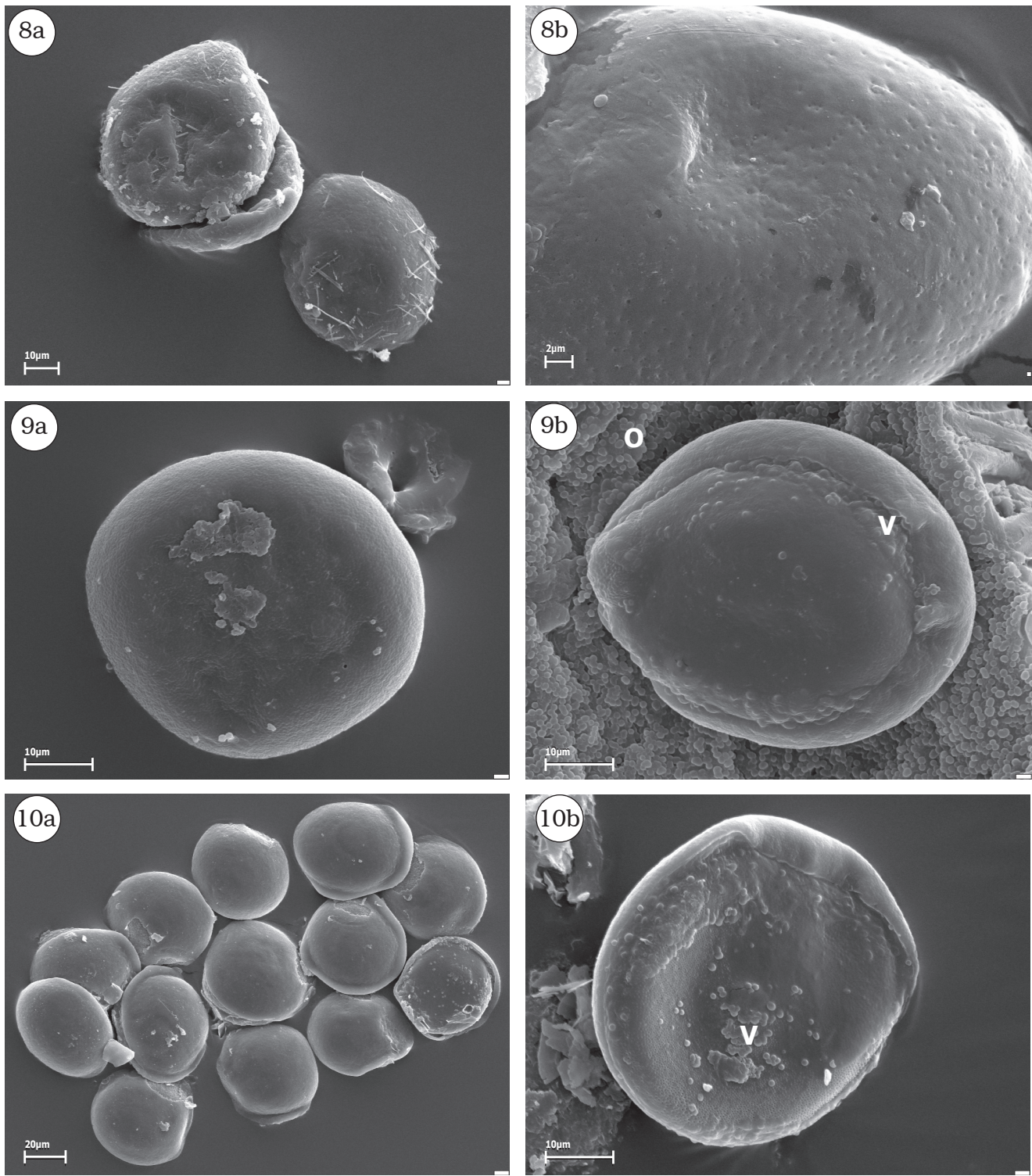

Figs. 8-10. SEM micrographs of pollen grains in Sansevieria: (8) S. parva (8a) in proximal and distal view, (8b) exine surface, enlargement of 8a; (9) S. pearsonii (9a) in proximal view, (9b) in distal view; (10) S. powellii (10a) in proximal and distal view, (10b) in distal view; $O$ - orbicule, $V$ - verrucae.

As shown in Table 1, this study for the first time describes pollen of species representing all sections and subsections of the genus Sansevieria delineated by Mansfeld (2015), including the type species for each section. So far, one can conclude, that the pollen grains do not present any useful characters for differentiation of these systematic groups. The dendrogram shows that all the examined Sansevieria species are divided into two groups with one species as an outgroup (Fig. 16). The first group comprises 11 species from sections: Sansevieria, Dracomima and Cephalantha, while the second group includes three species from sections Sansevieria and Cephalantha. Also the subsections are distributed throughout the dendrogram. A separate position is taken by S. cylindrica due to its very large pollen grains.

The study included S. sambiranensis, a Malagasy taxon, which is different in its morphology from all other Sansevieria species and which shows closer phylogenetic affinity to Dracaena (Lu and Morgan, 2014; Mansfeld, 2015). Noteworthy is the verrucate ornamentation of exine on distal surface (Fig. 13) different from other species of 

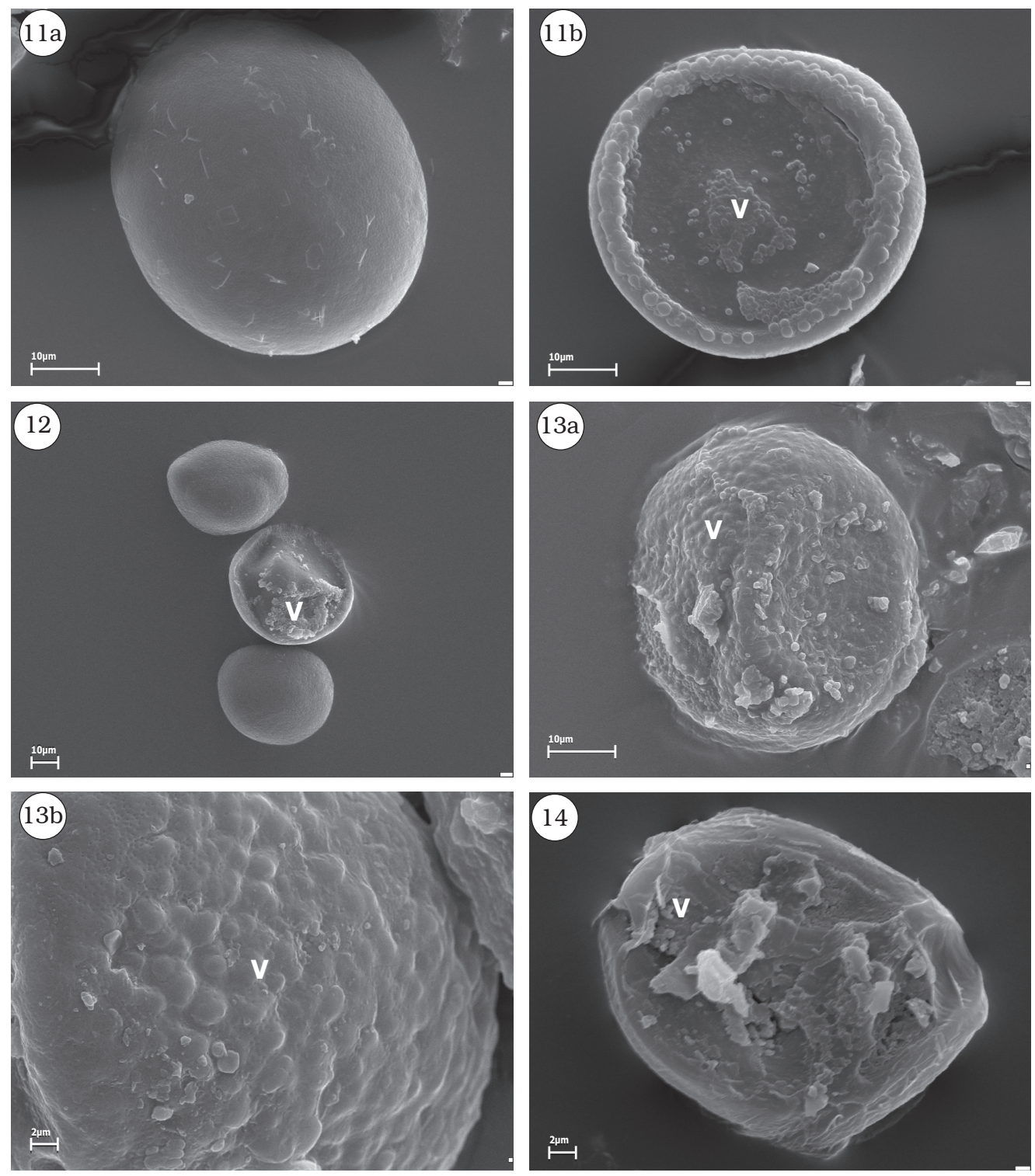

Figs. 11-14. SEM micrographs of pollen grains in Sansevieria: (11) S. perrotii (11a) in proximal view, (11b) in distal view; (12) S. roxburghiana in proximal and distal view; (13) S. sambiranensis (13a) in distal view, (13b) exine surface on distal face, (14) S. suffruticosa in distal view; $V$ - verrucae.

Sansevieria. Recently, S. dooneri has been treated as a synonym of S. parva (Mansfeld, 2015). Both species have soft, flat leaves without wall bands in water-storage (Koller and Rost, 1988) and without cuticular rims around stomata (Klimko et al., unpublished results). Unlike other morphological characters, the pollen grains of these two species are various in the exine ornamentation on the proximal surface: microreticulate in S. dooneri and psilate-perforate in S. parva. The taxonomic relation of these two taxa shall be reexamined in scope of other characters in the future.

\section{CONCLUSIONS}

The most important pollen grain features of the studied Sansevieria species comprise the size and exine ornamentation on the proximal and distal surfaces. On the basis of the examined features, it was impossible to isolate individual Sansevieria species but only their groups. The species belonging to these groups did not always derive from the same sections. The morphological characteristics of pollen grains described in this paper may be used in the comparison with 

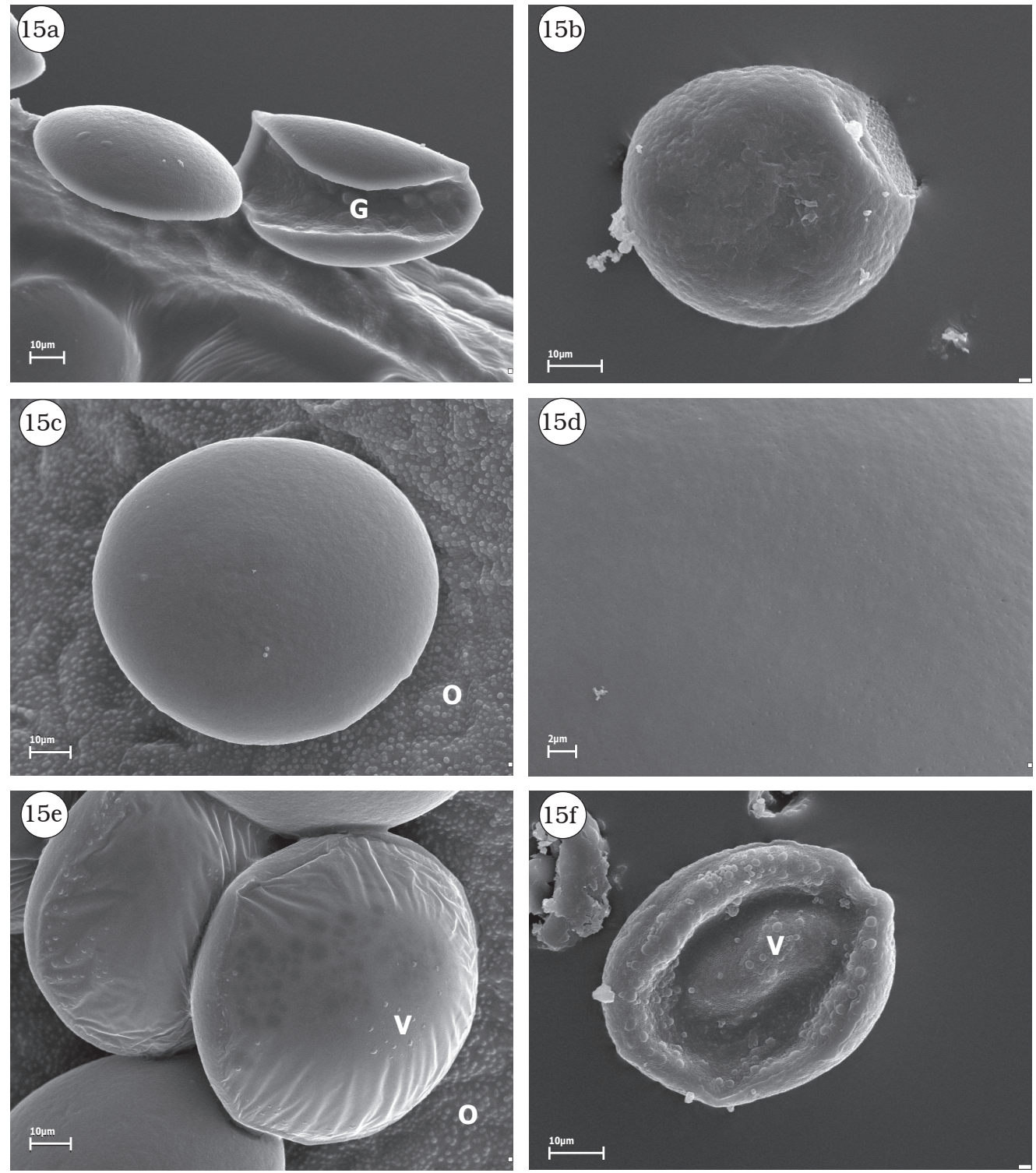

Fig. 15. SEM micrographs of pollen grains in Sansevieria trifasciata (a) proximal and lateral view, (b, c) in proximal view, (d) exine surface, enlargement of c, $(\mathbf{e}, \mathbf{f})$ in distal view; $G$ - gemmae, $O$ - orbicule, $V$ - verrucae.

species of the closely related genus Dracaena and for this reason these studies should be continued.

\section{AUTHORS' CONTRIBUTIONS}

The authors contributed to the conception of the research as well as collection analysis and data interpretation. PW, JW-SZ material collection and text editing; MK, RN, morphological analysis and text editing; MK micromorphological studies and photographs. The authors declare that there are no conflicts of interest.

\section{ACKNOWLEDGEMENTS}

We would like to express our gratitude to Wojciech Klimko (Poznań University of Life Sciences) for his assistance with computer data records. This work was carried out with the financial support from the National Science Center (grant no. N N303 807540), and the Department of Botany, Poznań University of Life Sciences and the Faculty of Biology, A. Mickiewicz University, Poznań. The authors would like to thank three anonymous reviewers for their suggestions and comments made on an earlier version of the manuscript. 


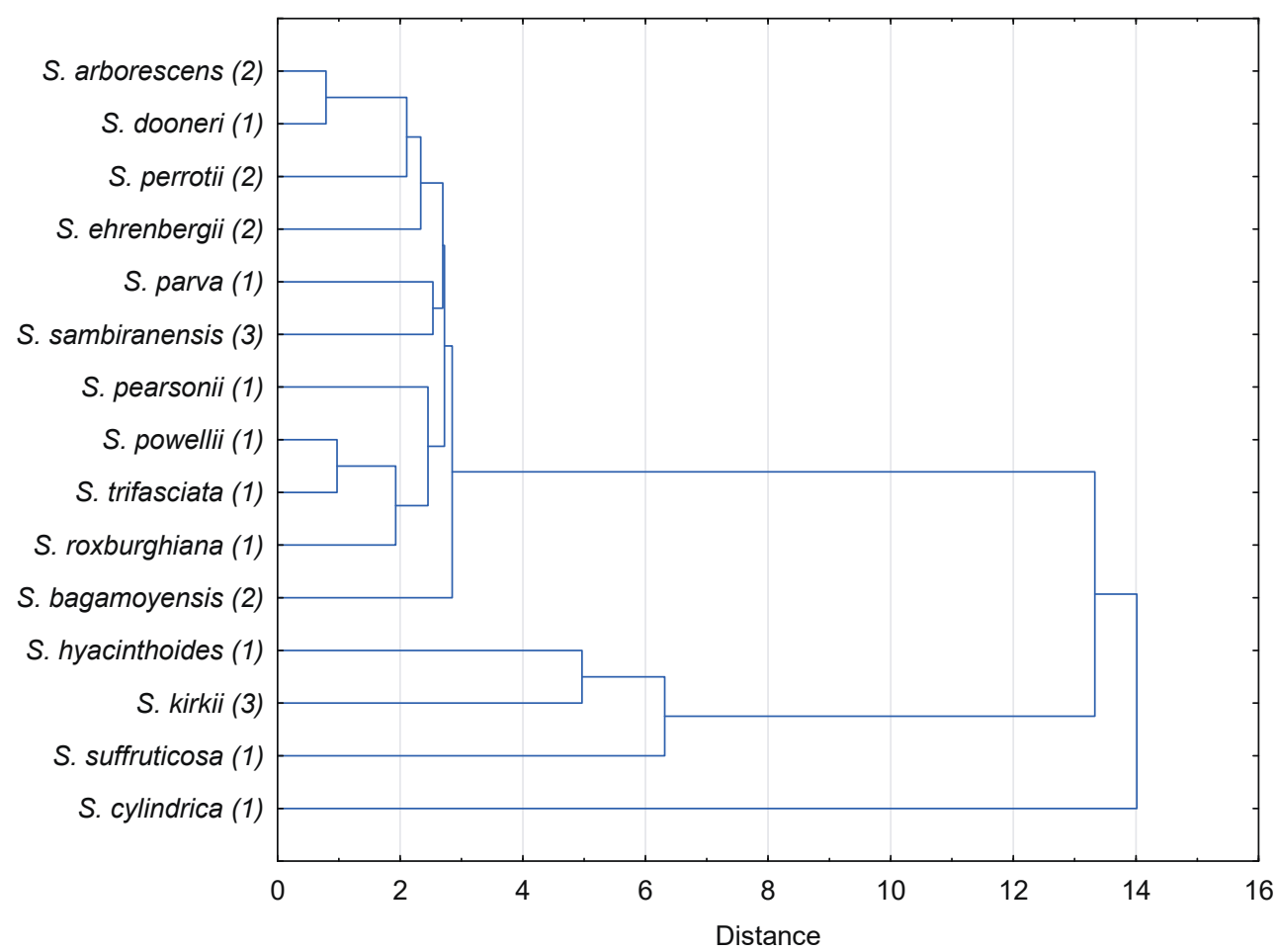

Fig. 16. Dendrogram of 15 Sansevieria species from sections Sansevieria (1), Dracomima (2) and Cephalantha (3) constructed on the basis of the shortest Euclidean distances.

TABLE 3. A comparison of separate character values of four Sansevieria species reported by the authors cited and the values found in our study.

\begin{tabular}{|c|c|c|c|c|c|c|}
\hline & \multirow[b]{2}{*}{ Species } & \multicolumn{4}{|c|}{ Characters (min-max, mean) } & \multirow{2}{*}{$\begin{array}{l}\text { Proximal } \\
\text { surface }\end{array}$} \\
\hline & & $\mathbf{L A}(\mu \mathrm{m})$ & $\mathbf{S A}(\mu \mathrm{m})$ & LA/SA & $\mathbf{E x}(\mu \mathrm{m})$ & \\
\hline $\begin{array}{l}\text { Ojeda et al. } \\
\text { (1984) }\end{array}$ & S. cylindrica & 73.4 & 58.8 & 1.75 & 1.79 & psilate \\
\hline our study & & 83.3 & 77.1 & 1.09 & 1.69 & $\begin{array}{c}\text { psilate- } \\
\text { perforate }\end{array}$ \\
\hline $\begin{array}{l}\text { Halbritter } \\
(2010)\end{array}$ & S. dooneri & $51-100$ & - & - & - & perforate \\
\hline our study & & $35.3-74.1$ & 48.7 & 1.22 & 1.74 & microreticulate \\
\hline $\begin{array}{l}\text { Buchner and } \\
\text { Halbritter } \\
(2010)\end{array}$ & S. suffruticosa & $51-100$ & - & - & - & perforate \\
\hline our study & & $60.0-91.8$ & 56.7 & 1.37 & 1.57 & $\begin{array}{l}\text { psilate- } \\
\text { perforate }\end{array}$ \\
\hline $\begin{array}{l}\text { Kameshwari } \\
\text { (2011) }\end{array}$ & S. roxburghiana & 35 & 15 & 2.33 & - & smooth \\
\hline our study & & 63.9 & 51.4 & 1.29 & 1.51 & $\begin{array}{l}\text { psilate- } \\
\text { perforate }\end{array}$ \\
\hline
\end{tabular}

Abbreviations: LA - length of long axis, SA - length of short axis, Ex - exine thickness. 


\section{REFERENCES}

APG II. 2003. An update of the Angiosperm Phylogeny Group classification for the orders and families of flowering plants. Botanical Journal of the Linnean Society 141: 399-436.

APG III. 2009. An update of the Angiosperm Phylogeny Group classification for the orders and families of flowering plants. Botanical Journal of the Linnean Society 161: 105-121.

AUDRAN JC 1984. Palinologia de la Familia Agavaceae para la peninsula de Yucatan. Biótica 9: 379-398.

AUDRAN JC, and MASURE E. 1978. La sculpture et l'infrastructure du sporoderme de Ginkgo biloba compárees à celles des enveloppes polliniques des cycadales. Review of Paleobotany and Palynology 26: 363-387.

Bos JJ. 1998. Draceanaceae. In:. Kubitzki K, (ed.). The families and genera of vascular plants 3. Monocotyledons, Lilianae (except Orchidaceae), Spirnger-Verlag, Heidelberg, New York.

BRown NE. 1915. Sansevieria. A monograph of all the known species. Bulletin of Miscellaneous Information (Royal Botanical Gardens, Kew) 5: 185-261.

Buchner R, and HALBRITTER H. 2010 onwards. Sansevieria suffruticosa. PalDat-a palynological database (https:/ www.paldat.org).

Chachinian BJ. 1985. The Sansevieria trifasciata dwarf cultivars: a beginning with no end. Cactacae Succulent Journal, (Los Angeles) 57: 199-203.

COUPER CJ. 2011. Sansevieria Thunberg. In: Cullen J, Kness SG, Cubey HS, (eds.), The European Garden Flora Flowering Plants. Angiospermae-Monocotyledons 1: 192-194.

CRonguist A. 1968. The evolution and classification of flowering plants. Boston: Houghton Mifflin Company.

Dyakowska J. 1959. Podręcznik palynologii, metody, problemy. Wydawnictwo Geologiczne, Warszawa

ERdtMan G. 1952. Pollen morphology and plant taxonomy, Angiosperms. Almqvist \& Wiksell, Stockholm.

ERDTMAn G, and Vishnu-MitTRE 1958. On terminology in pollen and spore morphology. Grana Palynological 1: 6-9.

FAEGRI K, and IvERSEN J. 1989. Textbook of pollen analysis. J. Wiley \& Sons, Chichester.

FREDERIKSEN NO. 1978. Preservation of cycad and Ginkgo pollen. Review of Paleobotany and Palynology 25(2): 163-179.

FURNESS CA, and RUDALL PJ. 1999. Inaperture pollen in monocotyledons. International Journal of Plant Sciences 160(2): 359-414.

FuRNESS CA, and RUDALl PJ. 2000. Aperture absence in pollen of Monocotyledons. In: Harley MM, Morton CM, Blackmore S. (eds.), Pollen and spores; morphology and biology. Kew, London. Royal Botanic Gardens.

FuRNESS CA, and RUDALL PJ. 2001. Pollen and anther characters in monocot systematics. Grana 40: 17-25.

HALbRitTer H. 2010 onwards. Sansevieria doonerii. PalDat a palynological database. (https:/www.paldat.org).

Halbritter H, and Hesse M. 1993: Sulcus morphology in some monocot families. Grana 32(2): 87-99.

Halbritter H, Werber M, Zetter R, Frosch-Radivo A, BuCHNER R, and HESSE M. 2007: Illustrated handbook on pollen terminology. Available at http://www.paldat.org/ paldat-Terminology-large.pdf.

Hesse M, Halbritter H, Zette R, Weber M, Buchner R, Frosch-Radivo A, and Ulrich S. 2009. Pollen terminology. An illustrated handbook. Springer, Vienna.

Hutchinson J. 1964. The families of flowering plants. Vol. II. Monocotyledons. Oxford University Press.

JANKALSKI S. 2009. The Sansevieria inflorescence and new sections proposed. Sansevieria 19(5): 8-10.

KAMESHWARI MN. 2011. Pollen morphology in some members of Liliaceae. International Journal of Engineering Science and Technology 3: 3825-3830.

Koller A, and Rost TL. 1988. Leaf anatomy in Sansevieria (Agavaceae). American Journal of Botany 75: 615-633.

Korszun S, and Klimko M. 2014. Microsporangia and pollen morphology of Ginkgo biloba cultivars. Dendrobiology 71: 83-92.

Lu PL, and Morden CW. 2014. Phylogenic relationships among Dracenoid genera (Asparagaceae: Nolinoideae) inferred from chloroplast DNA loci. Systematic Botany 39(1): 90-104.

MABBERLEY DJ. 2008. Mabberley's plant book. Cambridge. Cambridge Press.

MANSFEld P. 2015. Die Systematik der Gattung Sansevieria (Asparagaceae) - ein aktueller Stand. Sansevieria Online 3(1): 20-29.

MORGENSTERn KD. 1979. Sansevierias in pictures and words. Kempten, Germany: Illertalen Offsetdruck and Verlag GMBH.

Mwachala G, and Mbugua P. 2007. Dracaenaceae. In: Beentje HJ, Ghazanfar SA. (eds.), Flora of Tropical East Africa. Royal Botanical Gardens, Kew.

NEUWINGER HD. 1986. African ethnobotany; poisons and drugs: chemistry, pharmacology, toxicology. Weinheim; Chapman Hall.

OJeda Revah L, and Ludlow-Wiechers B. 1995. Palinologìa de Agavaceae, una contribución biosistemática. Boletin de la Sociedad Botánica México, 56: 25-43.

ÖZler H, and Pehlivan S. 2010. Pollen morphology of Allium L. (Liliaceae) taxa in Turkey. Bangladesh Journal of Botany 39(1): 37-46.

RudAll PJ, and CAMPBELl G. 1998. Flower and pollen structure of Ruscaceae in relation to Aspidistreae and other Convallariacea. Flora 194: 201-214.

Rudall PJ, ConRan JG, and Chase MW. 2000. Systematics of Ruscaceae / Convalariaceae: a combined morphological and molecular investigation. Botanical Journal of the Linnean Society 134: 73-92.

SAHASHi N, and Ueno J. 1986. Pollen morphology of Ginkgo biloba and Cycas revoluta. Canadian Journal of Botany 64: 3075-3078.

SALISBURY RA. 1866. The genera of plants. London, J. Van Voorst.

SAMPSON FB. 2000. Pollen diversity in some modern Magnoliids. International Journal of Plant Sciences 161(56): 193-210.

Staples GW, and Herbst DR. 2005. A Tropical Garden Flora. Bishop Museum Press, Honolulu, Hawaii, USA.

TAKHTAJAN A. 1969. Flowering plants: origin and dispersal. Washington DC, Smithsonian Institution Press. 
Tekleva MV, Polevova SV, and Zavialova NE. 2007. On some peculiarities of sporoderm structure in members of the Cycadales and Ginkgoales. Paleontological Journal 41(11): 1162-1178.

Wataza C. 2002. Biostatystyka. Alfa-Medica Press. BielskoBiała.

Watson L, DALlwitz MJ. 1992 onwards. The families of flowering plants: descriptions, illustrations, identification, and information retrieval (http://delta-intkey.com).

WrońsKa-Pilarek D, Halbritter H, KrzymińsKa A, Bednorz L, Bocianowski J. 2016. Pollen morphology of selected Eu- ropean species of the genus Allium L. (Alliaceae). Acta Scientarum Polonorum Hortorum Cultus 15(4): 65-84.

Zavialova N, Gordenko N, Nosova N, Polevova S. 2014. The fine morphology of pollen grains from pollen chamber of a supposed ginkgoalean seed from the Middle Jurassic of Uzbekistan (Angren locality). Plant Systematic and Evolution 300(9): 1995-2008.

Zavialova N, Markevich V, Bugdaeva E, Polevova S. 2011. The ultrastructure of fossil dispersed monosulcate pollen from the Early Cretaceous of Transbaikalia, Russia. Grana 50(13): 182-201. 